\title{
Changing Administrative Practices in American Unions: A Research Note
}

\author{
PAUL F. CLARK and LOIS S. GRAY*
}

\begin{abstract}
This note presents findings from the first longitudinal study of the administrative practices of American unions. Our surveys, conducted in 1990 and 2000, gathered information on the hiring, human resource, and financial/strategic planning practices of U.S.-based national and international unions. The results indicate that American unions are changing their criteria for hiring staff and moving toward more formal human resource policies and systematic financial and strategic planning practices.
\end{abstract}

IN RESPONSE TO DECLINING MEMBERSHIP AND SHRINKING RESOURCES, American labor unions have undergone significant changes in the past 20 years. In 1995, John Sweeney and the "New Voice" ticket won the first contested election for the leadership of the American Federation of Labor-Congress of Industrial Organizations (AFL-CIO) pledging to dramatically increase labor's efforts in organizing and political action. At the same time, some individual unions developed new collective bargaining strategies and consummated mergers that changed the landscape of the labor movement. These developments have been the subject of substantial academic research. Less visible, but also significant, were changes in union administrative practices.

Central to the success of all organizations, and long a focus of inquiry and innovation in business and government, administrative practices constitute the system by which organizations plan and organize work, select staff, allocate resources, and evaluate results. These processes are critical to the attainment of organizational goals. Despite their importance, union administrative practices have received limited attention from scholars.

This note highlights the first longitudinal study of these practices. Our surveys, conducted in 1990 and 2000, gathered information on the hiring,

\footnotetext{
* The authors' affiliations are, respectively, Department of Labor Studies and Industrial Relations, Penn State University, University Park, PA, and New York State School of Industrial and Labor Relations, Cornell University, New York, NY. E-mail: pfc2@psu.edu andlsg7@cornell.edu
} 
human resource, and financial/strategic planning practices of U.S.-based national and international unions. The results indicate that American unions, in a break from observed past practice, are changing their criteria for hiring staff and moving toward the formal human resource policies and systematic financial and strategic planning practices that characterize American business and government. ${ }^{1}$

\section{Data Collection}

In 1990, questionnaires were sent to 110 U.S. national and international unions. In 2000, similar questionnaires were sent to 88 of the unions surveyed in 1990. Both included a number of identical questions on hiring, human resource, financial, and strategic planning practices. Forty-eight completed questionnaires were returned in 1990 for a response rate of 44 percent. In 2000, 46 unions completed and returned surveys, a response rate of 52 percent. The evidence suggests that the sample returns for both years were representative of U.S. unions generally.

\section{Results and Analysis}

Selected survey results for 1990 and 2000 are presented in accompanying Table 1.

\section{Human Resource Policies}

Part I shows a major shift away from the traditional practice of hiring staff from inside the membership of the union. Specifically, the proportion of national unions requiring union membership for appointment to headquarters staff dropped from 38 percent in 1990 to 16 percent in 2000, and the proportion that hired field staff who had previously worked for other unions increased from 55 percent to 66 percent over the 10 -year period. Findings with respect to hiring criteria in 2000, reported in Part I, suggest reasons for the change. College degrees and computer skills are rated by the majority of respondents as "very important" or "somewhat important" in

\footnotetext{
${ }^{1}$ For a more detailed analysis of survey results and their implications, contact the authors-Paul Clark (pfc2@psu.edu) or Lois Gray (1sg7@cornell).
} 
TABLE 1

Union Administrative Practices

1990

I. Hiring practices

Percent of respondent unions who have:

Made current membership a qualification for appointment to headquarters staff $\quad \begin{array}{lll}38 & 16\end{array}$

$\begin{array}{lll}\text { Hired headquarters staff who have previously worked at another union } & 83 & 76\end{array}$

$\begin{array}{lll}\text { Hired field staff who have previously worked at another union } & 55 \quad 66\end{array}$

Percent of respondent unions who report:

College degrees for headquarters staff as very or somewhat important $\quad-\quad 80$

Computer skills for headquarters staff as very or somewhat important $\quad-\quad 88$

College degrees for field staff as very or somewhat important $\quad-\quad 58$

Computer skills for field staff as very or somewhat important $\quad-\quad 72$

Percent of respondent unions who use outside consultants to assist with:

Computer services

$69 \quad 83$

$\begin{array}{lll}\text { Economic analysis } & 35 & 43\end{array}$

Financial planning $\quad 25 \quad 30$

$\begin{array}{lll}\text { Health and welfare benefits } & 46 \quad 43\end{array}$

$\begin{array}{lrr}\text { Personnel recruitment } & 10 & 23\end{array}$

Public relations $\quad 52 \quad 59$

$\begin{array}{lll}\text { Training } & 35 & 50\end{array}$

II. Human resource practices

Percent of respondent unions with written policies for headquarters staff in the following areas:

$\begin{array}{llll}\text { Equal opportunity/affirmative action } & 46 & 59\end{array}$

$\begin{array}{lll}\text { Discipline and discharge } & 50 & 65\end{array}$

$\begin{array}{lll}\text { Hiring } & 42 & 48\end{array}$

$\begin{array}{lll}\text { Performance appraisal } & 33 & 50\end{array}$

$\begin{array}{lll}\text { Promotion } & 31 & 35\end{array}$

$\begin{array}{lll}\text { Salary review } & 35 & 37\end{array}$

Training $\quad 29 \quad 46$

Percent of respondent unions with written policies for field staff in the following areas:

$\begin{array}{lll}\text { Equal opportunity/affirmative action } & 42 & 54\end{array}$

$\begin{array}{lll}\text { Discipline and discharge } & 42 & 60\end{array}$

$\begin{array}{lll}\text { Hiring } & 40 & 41\end{array}$

$\begin{array}{lll}\text { Performance appraisal } & 25 & 41\end{array}$

$\begin{array}{lll}\text { Promotion } & 27 & 33\end{array}$

$\begin{array}{lll}\text { Salary review } & 35 & 37\end{array}$

$\begin{array}{lll}\text { Training } & 29 & 46\end{array}$

$\begin{array}{lll}\text { Percent of respondent unions that employ a human resources director } & 42 & 61\end{array}$

III. Union financial and strategic planning practices

Percent of unions that:

$\begin{array}{llll}\text { Develop an annual budget with planned expenditures by function or department } & 65 & 76\end{array}$

$\begin{array}{lll}\text { Employ a formal strategic planning process } & 40 & 67\end{array}$

$\begin{array}{lll}\text { Have a systematic evaluation process for planned activities } & 22 & 50\end{array}$

$\begin{array}{lll}\text { Have a formal organizational chart describing reporting relationships } & 51 & 71\end{array}$

$N=48 \quad N=46$ 
staff-hiring decisions, and 54.5 percent said that this rating represents a "significant change" or somewhat of a change "over the past 10 to 15 years." Over this period, unions also increased the employment of outside consultants to perform such functions as economic analysis, financial planning, organizational analysis, computer services, public relations, training, and personnel recruitment. Employment of consultants is consistent with the trend to seek staff talent from outside the ranks of the membership.

Unions have tended to lag behind government and business organizations in adopting formalized human resource policies. Part II indicates that they are moving in this direction by reducing these policies to writing and employing full-time human resource directors to administer them.

\section{Financial, Organizational, and Strategic Planning Practices}

Respondents were asked whether their union had developed an annual budget with planned expenditures by function or department. As Part III indicates, positive responses increased from 65 percent in 1990 to 76 percent in 2000. There was an even greater increase in the number of unions that reported having a formal strategic planning process (40 to 67 percent), systematic evaluation of planned activities (22 to 50 percent), and formal organization charts which describe reporting relationships (51 to 71 percent).

\section{Analysis by Membership Size}

When broken down by membership size, the data from the 2000 survey showed that large unions $(100,000$ members and over) were more likely to hire staff with experience in other labor organizations, have written personal policies, and employ a human resource director than were smaller unions (less than 100,000). Larger unions also led smaller unions in the percentage reporting formal budgets, strategic plans, and evaluation processes.

\section{Discussion}

The results of the 2000 survey, when analyzed in light of the 1990 study, suggest that American unions are increasingly adopting the more formal, systematic administrative practices, which are characteristic of business and 
government. Human resource practices in unions are changing. ${ }^{2}$ Placing less emphasis on membership status in hiring professional staff is a significant break from the past, as is the greater employment of outside consultants and the emphasis on professional qualifications for staff. The increasing employment of human resource directors and the advent of written personnel policies is further evidence of this trend, as is the increase in written personnel policies.

Finally, our survey results suggest that unions are engaging in more systematic administrative practices. Unlike the past, most unions now appear to create budgets and allocate resources by function and have formal organizational charts and strategic planning processes in place. These are all significant changes from traditional union practice.

What accounts for the shift to more formalized and professional administrative practices? Increasingly aggressive opposition by employers, declining financial resources, and member pressure for increased accountability in cost-benefit terms may account for greater union receptivity to these businesslike tools. More formal and consistent human resources policies may be perceived as generating greater job satisfaction and commitment among union employees and, in turn, may lower turnover and increase productivity; thus making unions more efficient. The trend may also be spurred by staff unionization. Underlying causes for change are questions for further investigation.

Not everyone in the labor movement necessarily sees these changes as positive developments. Undoubtedly some may be uncomfortable with this emulation of "business" methods. Critics of the trend toward more bureaucratic administrative practices may also see this as a "corporatization" of unions. They may fear that union leaders may begin to emulate other aspects of business organizations and, in the process, lose touch with their members.

In sum, the changes in administrative practices identified in this study are significant since they represent a break from tradition and a move toward increased efficiency and effectiveness. The findings should challenge labor scholars to look more closely at the internal operations of American labor organizations.

\footnotetext{
${ }^{2}$ For a description of traditional union administrative practices see Labor and the American Community, 1970, Derek C. Bok and John T. Dunlop, New York: Simon Schuster and The Management of Labor Unions, 1990, John T. Dunlop, Lexington, MA: Lexington Books.
} 